\title{
Selected biochemical parameters in the urine of HIV-infected patients in monitoring of kidney function
}

Beata Szymańska ${ }^{1}$, Zofia Marchewka ${ }^{1}$, Brygida Knysz ${ }^{2}$, Agnieszka Piwowar ${ }^{1}$

${ }^{1}$ Department of Toxicology, Faculty of Pharmacy, Wroclaw Medical University, Wroclaw, Poland

${ }^{2}$ Department of Infectious Diseases, Liver Diseases and Acquired Immune

Deficiencies, Faculty of Medicine, Wroclaw Medical University, Wroclaw, Poland

Submitted: 16 April 2020; Accepted: 19 July 2020;

Online publication: 18 April 2021

Arch Med Sci

DOI: https://doi.org/10.5114/aoms/114635

Copyright $\odot 2021$ Termedia \& Banach

\section{Abstract}

Introduction: For years, there has been an increase in the number of cases of chronic kidney disease (CKD) in human immunodeficiency virus (HIV)-infected patients. Renal dysfunction can be caused by direct effects of HIV on the kidneys but also of applied combined antiretroviral therapy (cART). Therefore there is a need of renal function diagnosis to monitor the development of kidney disturbances. In this study the urinary levels of selected low molecular weight proteins (LMWP) in HIV-infected patients were measured and related to current CD4+ T lymphocyte (LT CD4+) count, the glomerular filtration rate (eGFR) value and the applied cART.

Material and methods: The levels of 5 LMWP - kidney injury molecule-1 $(\mathrm{KIM}-1)$, neutrophil gelatinase associated lipocalin (NGAL), glutathione S-transferase $\alpha$ (GST- $\alpha$ ) and $\pi$ (GST- $\pi$ ) isoenzymes and neopterin (NPT) - in urine were measured in HIV-infected patients and healthy controls by enzyme-linked immunosorbent assay.

Results: Taking into account the current LT CD4+ count, KIM-1, NGAL and GST- $\alpha$ showed statistically significant differences between groups with the CD4+ count $<500$ and $\geq 500$ cells $(<0.001)$. Depending on the eGFR, apart from KIM-1 and NGAL, NPT showed statistically significant differences in the investigated groups with normal and lower eGFR values $(<0.001)$. In terms of applied CART, the best parameters in the assessment of kidney damage were NGAL, GST- $\pi$ and NPT $(<0.001)$.

Conclusions: This research shows that the analyzed LMWP parameters are useful in the assessment of kidney damage in HIV patients during CART, especially NPT, NGAL and GST- $\pi$. However, future studies should be conducted on larger groups.

Key words: low molecular weight proteins, HIV, CD4+ T lymphocytes, glomerular filtration rate, combination antiretroviral therapy.

\section{Introduction}

The number of acquired immunodeficiency syndrome (AIDS)-related deaths is the lowest this century, with fewer than 1 million people dying each year from AIDS-related illnesses, thanks to sustained access to antiretroviral therapy. The number of new human immunodeficiency virus (HIV) infections globally continued to decline in 2017. Modeled estimates show that new infections (all ages) declined from a peak of 3.4 million (2.6-4.4 million) in 1996 to 1.8 million (1.4-2.4 million) in 2017. The annu-

\author{
Corresponding author: \\ Beata Szymańska PhD \\ Department of Toxicology, \\ Faculty of Pharmacy \\ Wroclaw Medical University \\ 211 Borowska St \\ 50-556 Wroclaw, Poland \\ E-mail: beata.szymanska@ \\ umed.wroc.pl
}


al number of deaths in the world caused by AIDS, also regardless of age, dropped from 1.9 million in 2004 to 940,000 in 2017. Nonetheless, it is reported that HIV prevention services are not being provided on an adequate scale and with sufficient intensity and are not reaching the people who need them the most [1].

Constant expansion of knowledge about the human immunodeficiency virus has made it possible to improve the treatment methods of infected patients. The use of highly active antiretroviral therapy (HAART) resulted in both a decrease in mortality among seropositive patients and a decrease in the incidence of opportunistic infections and HIV/AIDS related cancers. The risk for the development of cancer in HIV-infected patients decreased after the introduction of HAART: Kaposi's sarcoma $(\mathrm{RR}=0.30,95 \% \mathrm{Cl}$ : 0.28-0.33) and non-Hodgkin's lymphoma $(\mathrm{RR}=0.52,95 \% \mathrm{Cl}$ : $0.48-0.56)$, in contrast to invasive cervical cancer $(\mathrm{RR}=1.46,95 \% \mathrm{Cl}: 1.09-1.94)$ [2].

Additionally, recent years have led to the development of uniform guidelines on antiretroviral therapy, the aim of which is to reduce viral load in peripheral blood and maintain this state for the longest possible time. According to 2018 recommendations, a reduction of viral load below 50 RNA copies of $\mathrm{HIV} / \mathrm{ml}$ is the goal of effective treatment [3].

However, the use of antiretroviral drugs for many years does not remain neutral to the patients. Among other things, an increase in cases of chronic kidney disease (CKD) in HIV-infected patients is observed $[4,5]$. The development of CKD is affected by both renal cell damage by HIV virus and co-infections with other viruses, as well as adverse and toxic effects of used drugs $[6,7]$.

Kidney impairments in HIV-infected patients are a major cause of morbidity and mortality. In some studies, kidney diseases were reported to double the risk of death in HIV-infected patients. On a worldwide scale, the prevalence of chronic kidney disease (CKD) among people living with HIV is estimated at $6.4 \%$. This prevalence varies across regions, being $7.9 \%$ in Africa, $7.1 \%$ in North America, $5.7 \%$ in Asia and $3.7 \%$ in Europe. In the African continent, West Africa has the highest rate, with a prevalence of $14.6 \%$, and Southern Africa is the least affected, with a prevalence of $3.2 \%$. The prevalence of HIV-associated nephropathy (HIVAN) decreased with the use of combined antiretroviral therapy (CART), but there remains a nearly 4-fold increased risk of kidney disease, including CKD, in people living with HIV compared with the general population [8].

This is an important problem in the care of HIV-positive patients. Therefore there is a need for constant diagnosis of renal function to monitor the development of CKD, prevention of the occurrence of end stage renal disease (ESRD), and optimization of therapy. For this reason searching for parameters which will allow diagnosis of kidney failure even at the level of subclinical changes is important. This would allow the implementation of appropriate nephroprotection or changing the treatment regimen. The world scientific data indicate a great interest in the subject of CKD development in HIV-infected patients; therefore undertaking research to determine the optimal and proper diagnosis of kidney dysfunction is appropriate and justified [5, 9].

Various biomarkers of renal function, measured in urine and serum, are in increasing use in order to estimate the severity and nature of kidney injury. Serum creatinine and the glomerular filtration rate (GFR), expressed as estimated GFR (eGFR), are still the most frequently used biomarkers of renal function despite their known limitations (such as in patients with low muscle mass or with fluid overload). Monitoring renal function in CKD requires biomarkers that provide rapid, noninvasive and specific measurements that correlate well with kidney tissue pathology. The possibility of performing the least invasive tests is particularly important, and therefore the use of urine for its measurement, as easily accessible biological material, is especially valuable. Promising parameters in the assessment of subclinical kidney damage may be low molecular weight proteins (LMWP), which appear in the urine relatively early, that is, before clinical changes manifested by renal structure disorders, or values of routine biochemical parameters such as serum creatinine [10].

The urinary concentrations of the following parameters were determined: kidney injury molecule-1 (KIM-1), neutrophil gelatinase associated lipocalin (NGAL), glutathione S-transferase $\alpha$ (GST- $\alpha$ ) and $\pi$ (GST- $\pi$ ) isoenzymes and neopterin (NPT).

KIM-1 and NGAL are proteins reflecting ischemic kidney damage, the GST- $\alpha$ isoenzyme located in the proximal tubules and GST- $\pi$ isoenzyme found in the cells of distal tubules and Henle's loop provide information about renal tubular dysfunction, and NPT is an indicator of cellular immunity.

The aim of this study was to evaluate the changes in the levels of five selected low molecular weight proteins in the urine of HIV-infected patients reflecting the functions of the kidneys, which underlines the non-invasive nature of this study.

\section{Material and methods}

The study group consisted of HIV-infected patients consulted in the HIV/AIDS Outpatient Clinic in Wroclaw in the period from 2011 to 2012. The control group included healthy volunteers, HIV 
negative individuals with eGFR ( $\geq 90 \mathrm{ml} / \mathrm{min})$ and any chronic or inflammatory diseases, such as hypertension, diabetes mellitus. There was no statistically significant difference between mean age of control group and HIV patients or between mean age of control group and all subgroups of HIV patients $(p>0.05)$.

In the group of patients, inclusion criteria were the patient's consent for tests, confirmation of the presence of HIV infection, and taking CART drugs. Exclusion criteria were diseases such as diabetes, cancer, hypertension and especially urinary tract diseases as well as concomitant use of drugs other than CART. The levels of these examined parameters were evaluated in three aspects. In the first analysis, the level of LMWP was assessed in relation to the CD4+ T lymphocyte (LT CD4+) count (with the CD4+ count $<500$ cells/ $\mu$ land $\geq 500$ cells/ $\mu \mathrm{l})$, allowing the intensity of HIV infection to be assessed. The second analysis took into account the value of eGFR, an indicator routinely used in the evaluation of renal function. The third analysis concerned the influence of cART on the value of LMWP, reflecting the effect of treatment as well as the action of the virus itself on the kidneys.

HIV-infected patients were divided according to the current LT CD4+ count into subgroups: HIVinfected patients with the LT CD4+ count $<500$ cells/ $\mu \mathrm{l}$ and HIV-infected patients with the LT CD4+ count $\geq 500$ cells $/ \mu$ l and depending on the value of eGFR into normal ( $\geq 90 \mathrm{ml} / \mathrm{min}$, and decreased eGFR (< $90 \mathrm{ml} / \mathrm{min}$ ). Additionally, HIV-infected patients were divided into four subgroups (I-IV) depending on the type of the CART: subgroup I patients with CART including tenofovir (TDF) with eGFR $<90 \mathrm{ml} / \mathrm{min}$; subgroup II - patients on CART including TDF with eGFR $\geq 90 \mathrm{ml} / \mathrm{min}$; subgroup III - patients on CART without TDF with eGFR $\geq 90 \mathrm{ml} / \mathrm{min}$; and subgroup IV - cART-naïve patients with $\mathrm{eGFR} \geq 90 \mathrm{ml} / \mathrm{min}$.

All participants were informed of the aim of the study and gave written consent to participate. The study was approved by the Ethics Committee of Wroclaw Medical University no. KB-658/2012.

The morning urine samples were collected in polystyrene containers (Aptaca, Italy), then centrifuged by an MPW-350 laboratory centrifuge (MPW Instruments, Poland) for 10 minutes $(1500 \times \mathrm{g})$, and then the obtained supernatant was removed and placed in Eppendorf tubes and stored at $-80^{\circ} \mathrm{C}$ for further investigation.

Low molecular weight protein concentrations were measured in urine by the immunoenzymatic method (ELISA) with Enzyme-Linked Immunosorbent Assay Kits: KIM-1 (BioAssay Works, USA, Cat. No. H-RENA-E-001), NGAL (BIOPORTO Diagnostics, Denmark, Cat. No. 036CE), GST- $\alpha$ (Nephkit Alpha, Argutus Medical Ltd, Ireland, Cat. No. BIO66NE-
PHA), GST- $\pi$ (Pi GST EIA, Argutus Medical Ltd, Ireland, Cat. No. BIO85), and NPT (IBL, Germany, Cat. No. RE59321) according to the manufacturer's instructions in a listed test.

Levels of LMWP were calculated in relation to the urine creatinine concentration estimated by Jaffe's routine method based on the reaction of picric acid (Picric Acid, USA, SIGMA, Cat. No. 319287) and creatinine under acidic conditions. This allowed the values of examined parameters to be expressed in the unit of level of $\mathrm{mg}$ of urine creatinine.

The study was conducted in the Department of Toxicology, Faculty of Pharmacy, Wroclaw Medical University.

Additionally, clinical parameters derived from medical records of HIV-infected patients (i.e. LT CD4+ count, eGFR value, antiretroviral treatment and serum creatinine concentration) were also used to interpret the results.

\section{Statistical analysis}

Statistical analysis was conducted with Statistica PL software (version 13.3). The normality of distribution was checked with Lilliefors and Kolmogorov-Smirnov tests. The nonparametric Kruskal-Wallis test was used for the comparison of the variables between groups and the post hoc analysis (Bonferroni test) for nonparametric data was used. The diagnostic value of each parameter was assessed using receiver operating characteristic curve (ROC) analysis. The values of diagnostic indicators (sensitivity, specificity; positive predictive (PPV), negative predictive (NPV), likelihood ratio $(\mathrm{LR}+/-)$ and their confidence interval $\mathrm{Cl}$ 95\% were calculated. The associations between continuous variables were analyzed by the Spearman test. The values of $p<0.05$ were considered as statistically significant.

\section{Results}

The patient group consisted of 86 HIV-infected patients including 48 men (77\%) and 20 women (23\%), with a mean age of 42 years. The control group included 34 healthy volunteers, HIV negative individuals: 25 men (74\%) and 9 women (26\%) with a mean age 39 years. The demographic and clinical characteristics of examined groups are shown in Table I. No statistically significant differences in characteristics between HIV-infected patients and the control group were observed.

In HIV-infected patients divided into subgroups according to the LT CD4+ count $<500$ cells/ $\mu \mathrm{l}$ and HIV-infected patients with the LT CD4+ count $\geq 500$ cells $/ \mu \mathrm{l}$, and the control group, the median levels and interquartile ranges with statistical analysis of examined low molecular weight pro- 
Table I. Demographic and clinical data of HIV patients and the control group

\begin{tabular}{|c|c|c|}
\hline Population characteristic & $\begin{array}{l}\text { HIV-infected } \\
\text { patients }\end{array}$ & $\begin{array}{l}\text { Control } \\
\text { group }\end{array}$ \\
\hline$n(\%)$ & $86(100)$ & $34(100)$ \\
\hline Age, range [years] & $42(23-61)$ & $39(25-60)$ \\
\hline Male & $48(77)$ & $25(74)$ \\
\hline LT CD4+count $<500$ cells $/ \mu l$ & $45(52)$ & \\
\hline Age, range [years] & $44(31-60)$ & \\
\hline Male & $28(33)$ & \\
\hline LT CD4+count $\geq 500$ cells $/ \mu \mathrm{l}$ & $41(48)$ & \\
\hline Age, range [years] & $41(23-61)$ & \\
\hline Male & $35(40)$ & \\
\hline $\mathrm{EGFR}<90 \mathrm{ml} / \mathrm{min}$ & $28(39)$ & \\
\hline Age, range [years] & $45(23-60)$ & \\
\hline Male & $19(27)$ & \\
\hline $\mathrm{EGFR} \geq 90 \mathrm{ml} / \mathrm{min}$ & $43(61)$ & \\
\hline Age, range [years] & $42(28-61)$ & \\
\hline Male & $38(54)$ & \\
\hline \multicolumn{3}{|l|}{ Subgroups of cART therapy } \\
\hline Subgroup I & $23(27)$ & \\
\hline Age, range [years] & $47(28-60)$ & \\
\hline Male & $18(78)$ & \\
\hline Subgroup II & $22(26)$ & \\
\hline Age, range [years] & $40(28-58)$ & \\
\hline Male & $19(86)$ & \\
\hline Subgroup III & $21(24)$ & \\
\hline Age, range [years] & $45(28-61)$ & \\
\hline Male & $15(71)$ & \\
\hline Subgroup IV & $20(23)$ & \\
\hline Age, range [years] & $37(23-58)$ & \\
\hline Male & $14(70)$ & \\
\hline
\end{tabular}

eGFR - estimated glomerular filtration rate, $L T C D 4+-l y m p h o c y t e s$ $T$ CD4+, subgroup I - patients on CART including tenofovir (TDF) with eGFR $<90 \mathrm{ml} / \mathrm{min}$, subgroup II - patients on CART including $T D F$ with eGFR $\geq 90 \mathrm{ml} / \mathrm{min}$, subgroup III - patients on CART without TDF with eGFR $\geq 90 \mathrm{ml} / \mathrm{min}$, subgroup IV - CART-naïve patients with $e G F R \geq 90 \mathrm{ml} / \mathrm{min}$

teins (KIM-1, NGAL, GST- $\alpha$, GST- $\pi$, NPT) are presented in Table II and Figure 1.

As shown in Table II, median levels of KIM1, NGAL, GST- $\alpha$ and NPT were 3.7-fold, 3-fold, 1.6-fold and 2.9-fold higher, respectively, in the subgroup of HIV-infected patients with LT CD4+ $<500$ cells $/ \mu$ l compared with the control group. Median levels of KIM-1, NGAL, GST- $\alpha$ and NPT were increased 3-fold, 2.6-fold, 1.5-fold and 1.2-fold, respectively, in the HIV-infected patients with the LT CD4+ count $\geq 500$ cells/ $\mu$ l compared with the control group. Similar median levels in both subgroups and the control group were observed only for GST- $\pi$. There were no statistical- ly significant differences between the levels of KIM-1, NGAL, GST- $\alpha$, GST- $\pi$ and NPT in the subgroup of HIV-infected patients with LT CD4+ $<500$ cells $/ \mu \mathrm{l}$ and in the HIV-infected patients with the LT CD4+ count $\geq 500$ cells/ $\mu$ (Table II).

Based on ROC analysis, the best diagnostic value in the subgroup of HIV-infected patients with LT CD4+ < 500 cells/ $\mu$ l was observed for NGAL [area under the curve (AUC) of 0.77 (95\% confidence interval $(\mathrm{Cl}) 0.67-0.87, p<0.001)$ ] and KIM-1 [AUC of 0.75 (95\% Cl: 0.67-0.87, $p<0.001)$ ] (Figure 2). By contrast, in the subgroup of HIVinfected patients with LT CD4+ $\geq 500$ cells $/ \mu \mathrm{l}$ the best diagnostic value was observed for NGAL [AUC of 0.78 (95\% Cl: $0.68-0.88, p<0.001)$ ] (Figure 2, Table VI).

In both subgroups of patients in terms of LT CD4+ count, significant positive correlations between GST- $\alpha$ and GST- $\pi(R=0.564, p<0.001$; $R=0.740, p<0.001$, respectively) and between NPT and serum creatinine $(R=0.342, p=0.029$; $R=0.573, p<0.001$, respectively) were revealed. Negative significant correlations between KIM-1 and NGAL $(R=-3.714, p=0.017)$ in the group of HIV-infected patients with LT CD4+ count $\leq 500$ cells/ $\mu \mathrm{l}$ were found.

The median levels of KIM-1, NGAL and NPT were 5.3-fold, 3.3-fold and 7-fold higher, respectively, in HIV-infected patients with eGFR $<90 \mathrm{ml}$ min compared to the control group. Median levels of KIM-1 and NGAL were 2.6-fold and 2-fold higher, respectively, in HIV-infected patients with eGFR $\geq$ $90 \mathrm{~m} / \mathrm{min}$ compared to the control group. Similar median levels in both subgroups and the control group were observed for GST- $\alpha$ and GST- $\pi$. Statistically significant differences between NPT level in HIV-infected patients with eGFR $<90 \mathrm{ml} / \mathrm{min}$ and in HIV-infected patients with eGFR $\geq 90 \mathrm{ml}$ min were found. The post hoc analysis showed no significant differences between KIM-1, NGAL, GST- $\alpha$, and GST- $\pi$ levels in HIV-infected patients with eGFR $<90 \mathrm{ml} / \mathrm{min}$ and in HIV-infected patients with eGFR $\geq 90 \mathrm{ml} / \mathrm{min}$ (Table III, Figure 1).

The parameters with the highest diagnostic value in HIV-infected patients with eGFR $<90 \mathrm{ml} / \mathrm{min}$ included: NPT [AUC of $0.89(95 \% \mathrm{Cl}: 0.79-0.99$, $p<0.001)$ ], NGAL [AUC of 0.88 (95\% Cl: 0.78-0.96, $p<0.001)$ ], KIM-1 [AUC of 0.73 (95\% Cl: 0.59-0.86, $p<0.001)$ ] and GST- $\alpha$ [AUC of $0.71(95 \% \mathrm{Cl}$ : $0.59-0.84, p<0.001$ )] (Figure 2, Table VI).

In subgroups with HIV-infected patients with eGFR $<90 \mathrm{ml} / \mathrm{min}$ and HIV-infected patients with eGFR $\geq 90 \mathrm{ml} / \mathrm{min}$ a significant positive correlation was demonstrated between GST- $\alpha$ and GST- $\pi$ $(R=0.876, p<0.001 ; R=0.689, p<0.001$, respectively) but a correlation for NPT and serum creatinine ( $R=0.376, p=0.049)$ was revealed only in HIV-infected patients with the eGFR $<90 \mathrm{ml} / \mathrm{min}$. 
Table II. Median levels and interquartile ranges of low molecular weight proteins in the urine of HIV patients in the subgroups separated on the basis of the number of LT CD4+ with statistical analysis

\begin{tabular}{|c|c|c|c|c|c|c|c|c|}
\hline \multirow{2}{*}{$\begin{array}{l}\text { Subgroups } \\
\text { LMWP }\end{array}$} & \multicolumn{2}{|c|}{$\begin{array}{c}\text { CD4+ }<500 \text { cells } / \mu \mathrm{l} \\
\text { (A) }\end{array}$} & \multicolumn{2}{|c|}{$\begin{array}{c}\text { CD4+ } \geq 500 \text { cells } / \mu l \\
\text { (B) }\end{array}$} & \multicolumn{2}{|c|}{$\begin{array}{l}\text { Control group } \\
\text { (C) }\end{array}$} & \multirow[t]{2}{*}{$P$-value* } & \multirow[t]{2}{*}{$\begin{array}{l}\text { Post hoc } \\
\text { analysis }\end{array}$} \\
\hline & $\mathrm{Me}$ & IQR & $\mathrm{Me}$ & IQR & $\mathrm{Me}$ & IQR & & \\
\hline $\begin{array}{l}\mathrm{KIM}-1 \\
{[\mathrm{ng} / \mathrm{mg} \mathrm{cr} .]}\end{array}$ & 0.11 & $0.07-0.22$ & 0.09 & $0.03-0.15$ & 0.03 & $0.02-0.08$ & $<0.001$ & $\begin{array}{c}A: C<0.001 \\
B: C=0.045 \\
A: B=N S\end{array}$ \\
\hline $\begin{array}{l}\text { NGAL } \\
{[\mathrm{ng} / \mathrm{mg} \mathrm{cr} .]}\end{array}$ & 23.08 & $10.54-44.64$ & 19.52 & $12.11-35.93$ & 7.57 & $3.65-14.57$ & $<0.001$ & $\begin{array}{c}A: C<0.001 \\
B: C<0.001 \\
A: B=N S\end{array}$ \\
\hline $\begin{array}{l}\text { GST- } \alpha \\
{[\mathrm{ng} / \mathrm{mg} \mathrm{cr} .]}\end{array}$ & 2.72 & $1.84-5.39$ & 2.44 & $1.77-3.66$ & 1.72 & $1.06-2.80$ & 0.012 & $\begin{aligned} A: C & =0.025 \\
B: C & =0.026 \\
A: B & =N S\end{aligned}$ \\
\hline $\begin{array}{l}\text { GST- } \pi \\
{[\mathrm{ng} / \mathrm{mg} \mathrm{cr} .]}\end{array}$ & 4.67 & $2.55-7.43$ & 3.07 & $1.99-6.91$ & 3.24 & $2.18-4.14$ & 0.049 & $\begin{array}{c}A: C=0.044 \\
B: C=N S \\
A: B=N S\end{array}$ \\
\hline $\begin{array}{l}\text { NPT } \\
{[\mathrm{ng} / \mathrm{mg} \mathrm{cr} .]}\end{array}$ & 177.26 & $28.27-384.07$ & 74.89 & $37.14-263.07$ & 59.76 & $30.95-115.15$ & NS & $\begin{array}{l}A: C=N S \\
B: C=N S \\
A: B=N S\end{array}$ \\
\hline
\end{tabular}

Me - median, IQR - interquartile range, LMWP - low molecular weight proteins, CD4+ - lymphocytes T, NS - not statistically significant. ${ }^{\star}$ Kruskal-Wallis test

Neopterin also showed a negative correlation with eGFR $(R=-0.603, p=0.001)$ in the whole group of HIV-infected patients. The mean value of serum creatinine in HIV-infected patients was 0.89 (median $=0.88) \mathrm{mg} / \mathrm{dl}$ and was significantly higher compared to the control group, 0.78 (median = $0.77) \mathrm{mg} / \mathrm{dl}(p<0.001)$.

A comparative analysis of LMWP subgroups with LT CD4+ count < 500 cells/ $\mu$ land the eGFR $<90 \mathrm{ml} / \mathrm{min}$ vs. LT CD4+ count $\geq 500$ cells/ $\mu \mathrm{l}$ and the eGFR $\geq 90 \mathrm{ml} / \mathrm{min}$ was performed. In the last above-mentioned subgroup, only NGAL showed a statistically significant difference compared to the control group (Table IV).

Additionally, median levels and interquartile ranges of the LMWP for four subgroups (I-IV) of HIV-infected patients divided depending on the type of antiretroviral treatment with statistical analysis were estimated and the results are presented in Table $\mathrm{V}$ and Figure 1.

The highest median levels of KIM-1 and NGAL were observed in patients on CART including TDF with decreased eGFR (I subgroup) and in patients on CART without TDF treatment (subgroup III).

The median levels of KIM-1 and NGAL were 5.3fold and 3.3-fold higher, respectively, in subgroup I compared with the control group. The median levels of KIM-1 and NGAL were 3.7-fold and 3.7-fold higher, respectively, in subgroup III than the control group.

A statistically significant difference in examined LMWP level between group I and the control group was found only for KIM-1. However, statistically significant differences in NGAL level were detected between all subgroups (I-IV) and the control group.
The median levels of GST- $\alpha$ in all subgroups (I-IV) were similar and no statistically significant differences in GST- $\alpha$ level between any of the four groups compared to the control group or between these subgroups were found.

The highest median levels of GST- $\pi$ were observed in patients on CART without TDF treatment (subgroup III) and in cART-naïve patients (subgroup IV). The median levels of GST- $\pi$ were 2.1 -fold and 1.9-fold higher, respectively, in subgroups III and IV compared with the control group, and the difference between these subgroups and the control group was statistically significant.

The highest median levels of NPT were observed in patients on CART including TDF with decreased eGFR (subgroup I) and in cART-naïve patients (subgroup IV). The median levels of NPT were 7.5-fold and 1.7-fold higher, respectively, in subgroups III and IV compared with the control group. There were statistically significant differences in the NPT level when comparing subgroup I to subgroups II, III, IV and the control group (Table IV, Figure 1).

The parameters with the highest diagnostic value in subgroup I were: NPT [AUC of $0.99(95 \% \mathrm{Cl}$ : $0.88-1, p<0.001)$ ], NGAL [AUC of $0.91(95 \% \mathrm{Cl}$ : $0.59-0.89, p<0.001)$ ], KIM-1 [AUC of $0.74(95 \% \mathrm{Cl}$ : $0.59-0.88, p=0.001)]$ and GST- $\alpha$ [AUC of 0.71 (95\% Cl: 0.57-0.84, $p=0.003$ )] (Figure 3, Table VI).

Neutrophil gelatinase associated lipocalin had the best diagnostic value in subgroup III: sensitivity $71 \%$, specificity $100 \%$, AUC of $0.82(95 \% \mathrm{Cl}$ : $0.69-0.95, p<0.001$ ), while GST- $\pi$ had the best diagnostic value in subgroup IV: sensitivity $65 \%$, specificity $80 \%$, AUC of 0.75 (95\% Cl: $0.61-0.89$, $p<0.001)$. 

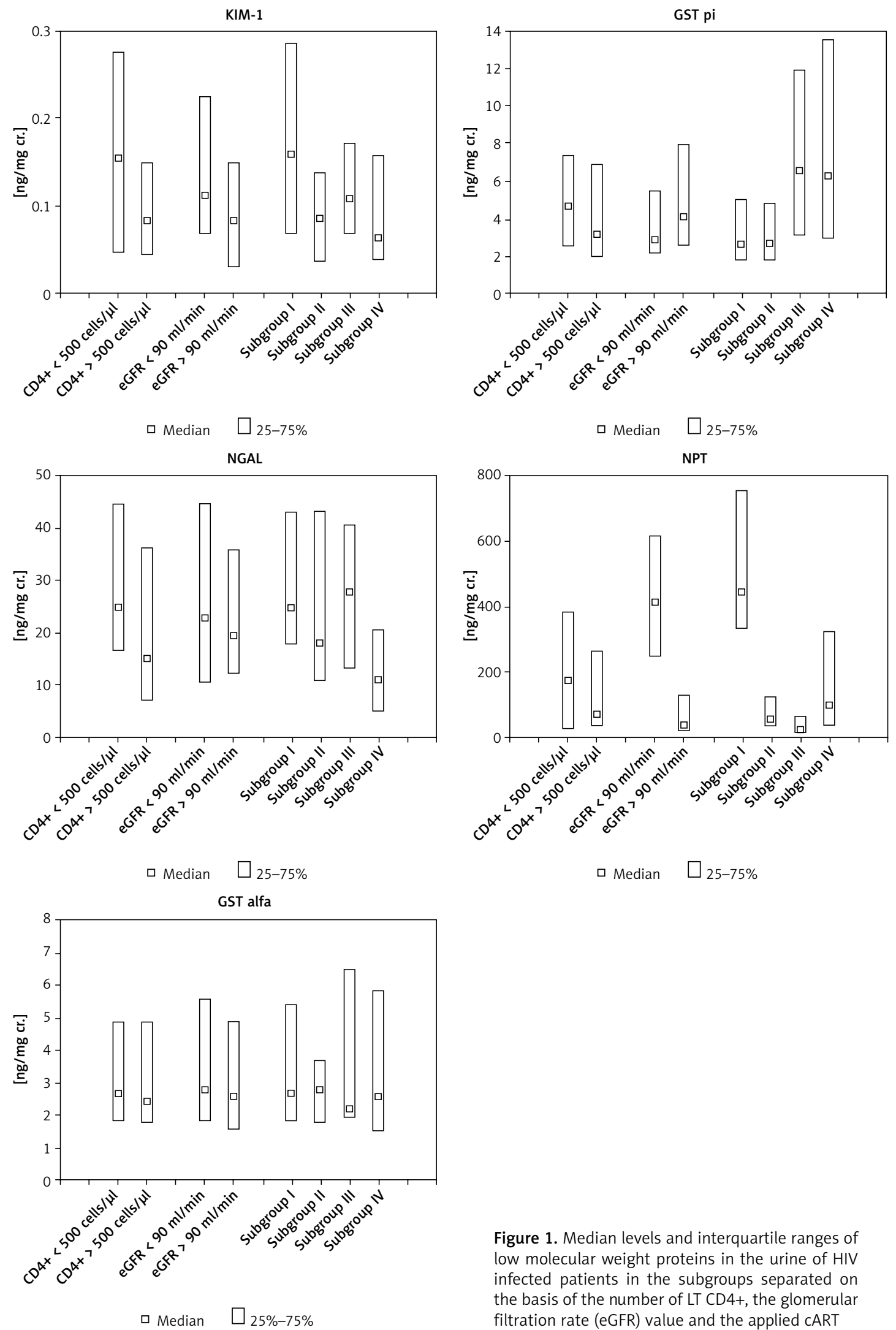

Figure 1. Median levels and interquartile ranges of low molecular weight proteins in the urine of HIV infected patients in the subgroups separated on the basis of the number of LT CD4+, the glomerular filtration rate (eGFR) value and the applied cART

\section{Discussion}

The present study evaluated changes in levels of five selected low molecular weight proteins -

KIM-1, NGAL, GST- $\alpha$, GST- $\pi$ and NPT - as potential parameters useful for the assessment of renal injury in HIV-infected patients depending on the LT CD4+ count, eGFR values and applied cART. 
ROC of KIM-1 in subgroup with CD4+ $<500$ cells $/ \mu \mathrm{l}$ Youden's Index $=0.49$; Cut off 0.07

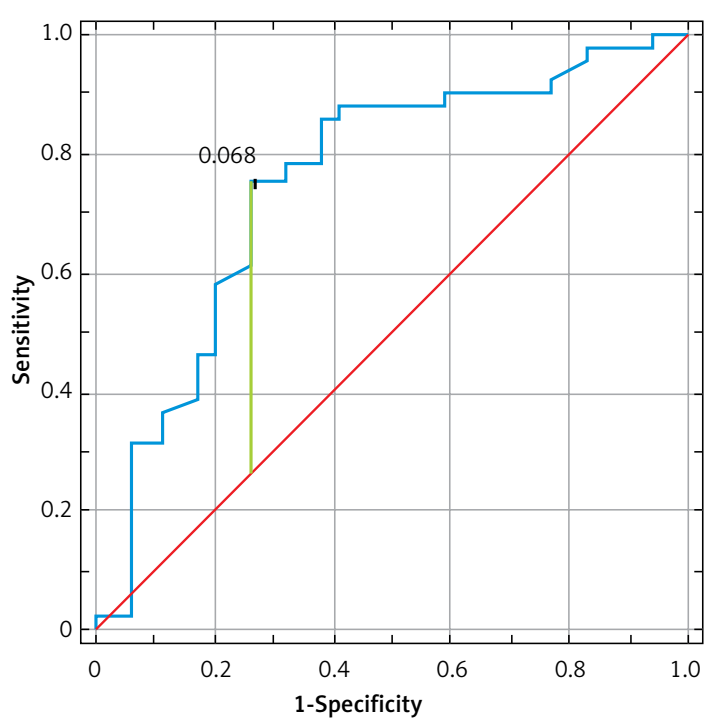

ROC of NPT in subgroup with GFR $<90 \mathrm{ml} / \mathrm{min}$ Youden's Index $=0.82$; Cut off 202.83

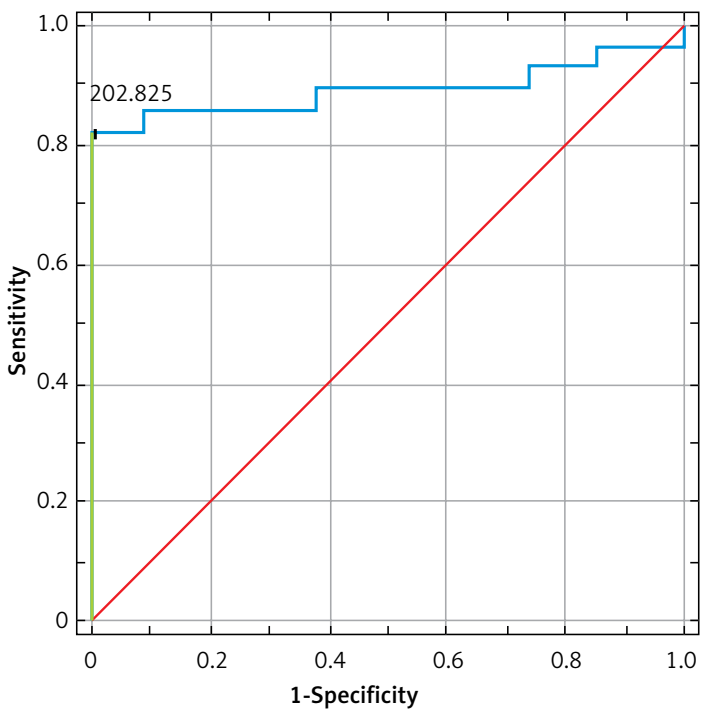

ROC of KIM-1 in subgroup with GFR $<90 \mathrm{ml} / \mathrm{min}$ Youden's Index $=0.47$; Cut off 0.10

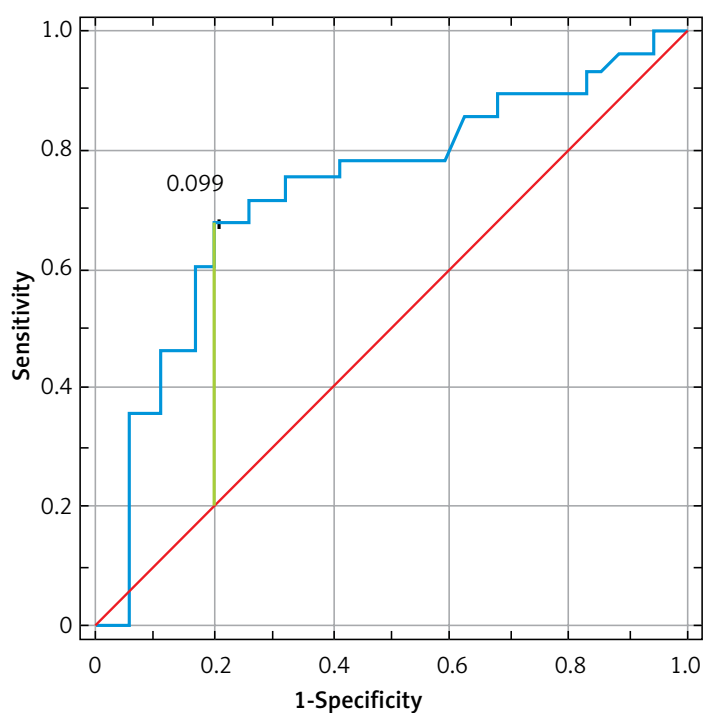

ROC of NGAL in subgroup with CD4 $+<500$ cells $/ \mu \mathrm{l}$ Youden's Index $=0.54$; Cut off 21.96

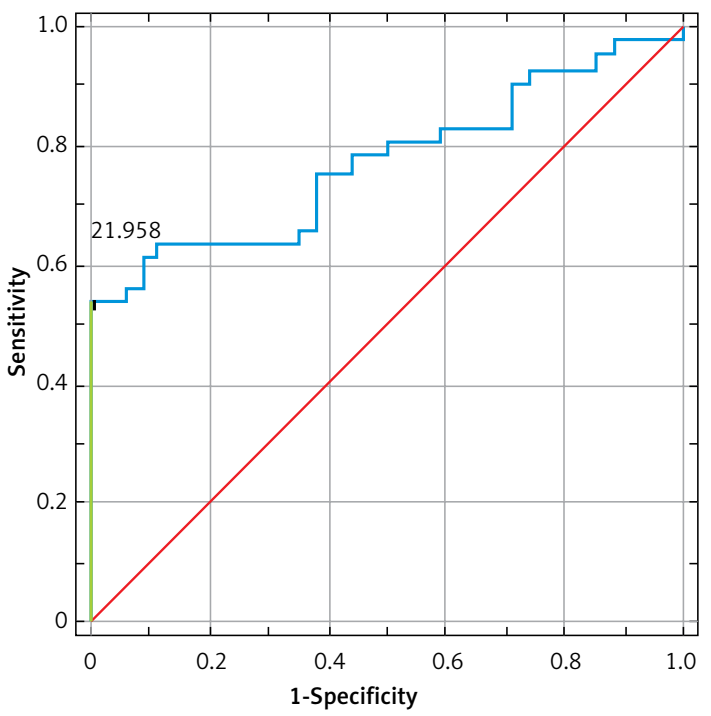

ROC of NGAL in subgroup with GFR $<90 \mathrm{ml} / \mathrm{min}$ Youden's Index $=0.66$; Cut off 17.71

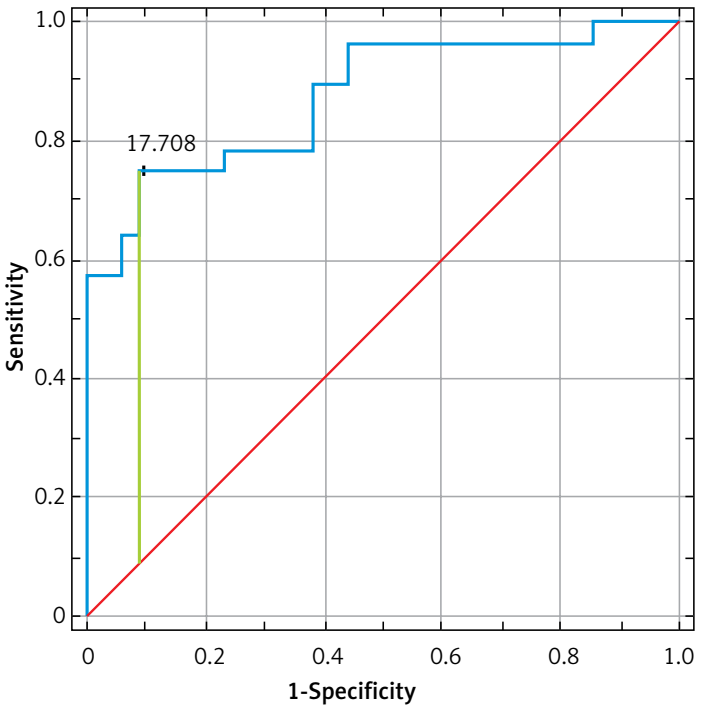

ROC of GST- $\alpha$ in subgroup with GFR $<90 \mathrm{ml} / \mathrm{min}$ Youden's Index $=0.38$; Cut off 1.82

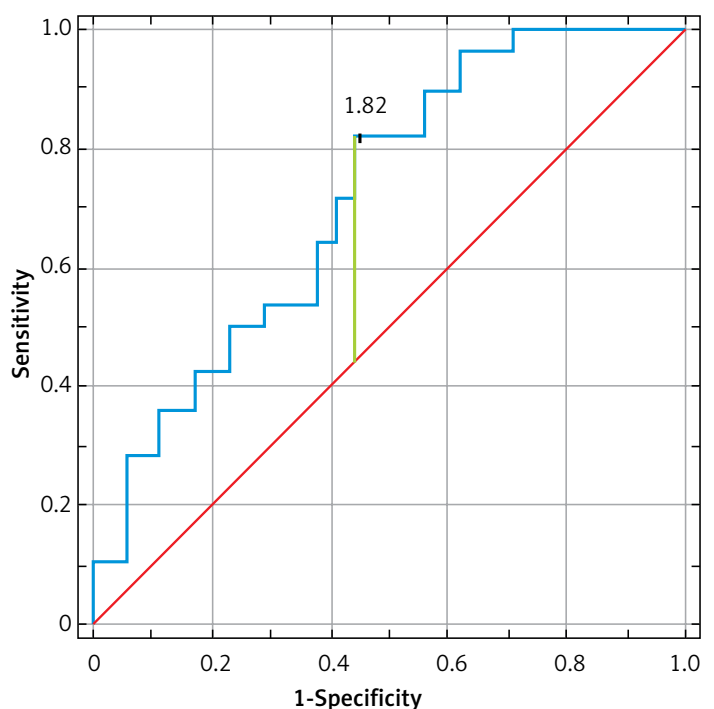

Figure 2. ROC curves of selected parameters in the group with LT CD4+ count $<500$ cells/ $\mu$ l and in the group with GFR $<90 \mathrm{ml} / \mathrm{min}$ 
Table III. Median levels and interquartile ranges of HIV patients in the subgroups separated depending on eGFR with statistical analysis

\begin{tabular}{|c|c|c|c|c|c|c|c|c|}
\hline \multirow{2}{*}{$\begin{array}{l}\text { Subgroups } \\
\text { LMWP }\end{array}$} & \multicolumn{2}{|c|}{$\begin{array}{c}\mathrm{EGFR}<90 \mathrm{ml} / \mathrm{min} \\
\text { (A) }\end{array}$} & \multicolumn{2}{|c|}{$\begin{array}{c}\mathrm{EGFR} \geq 90 \mathrm{ml} / \mathrm{min} \\
\text { (B) }\end{array}$} & \multicolumn{2}{|c|}{$\begin{array}{l}\text { Control group } \\
\text { (C) }\end{array}$} & \multirow[t]{2}{*}{$P$-value* } & \multirow[t]{2}{*}{$\begin{array}{l}\text { Post hoc } \\
\text { analysis }\end{array}$} \\
\hline & $\mathrm{Me}$ & IQR & $\mathrm{Me}$ & IQR & $\mathrm{Me}$ & IQR & & \\
\hline $\begin{array}{l}\mathrm{KIM}-1 \\
{[\mathrm{ng} / \mathrm{mg} \mathrm{cr} .]}\end{array}$ & 0.16 & $0.05-0.28$ & 0.08 & $0.04-0.15$ & 0.03 & $0.02-0.08$ & $<0.001$ & $\begin{array}{c}A: C<0.001 \\
B: C=0.023 \\
A: B=N S\end{array}$ \\
\hline $\begin{array}{l}\text { NGAL } \\
{[\mathrm{ng} / \mathrm{mg} \mathrm{cr} .]}\end{array}$ & 24.91 & $16.57-44.66$ & 15.14 & $7.15-36.22$ & 7.57 & $3.65-14.57$ & $<0.001$ & $\begin{array}{c}A: C<0.001 \\
B: C<0.001 \\
A: B=N S\end{array}$ \\
\hline $\begin{array}{l}\text { GST- } \alpha \\
{[\mathrm{ng} / \mathrm{mg} \mathrm{cr} .]}\end{array}$ & 2.81 & $1.94-6.49$ & 2.62 & $1.55-5.85$ & 1.72 & $1.06-2.80$ & 0.008 & $\begin{array}{c}A: C=0.012 \\
B: C=N S \\
A: B=N S\end{array}$ \\
\hline $\begin{array}{l}\text { GST- } \pi \\
\text { [ng/mg cr.] }\end{array}$ & 2.97 & $2.19-5.46$ & 4.19 & $2.55-7.99$ & 3.24 & $2.18-4.14$ & NS & $\begin{array}{l}A: C=N S \\
B: C=N S \\
A: B=N S\end{array}$ \\
\hline $\begin{array}{l}\text { NPT } \\
\text { [ng/mg cr.] }\end{array}$ & 415.39 & $251.38-615.34$ & 43.79 & $20.18-129.32$ & 59.76 & $30.95-115.15$ & $<0.001$ & $\begin{array}{c}A: C<0.001 \\
B: C=N S \\
A: B<0.001\end{array}$ \\
\hline
\end{tabular}

Me - median, IQR - interquartile range, LMWP - low molecular weight proteins, eGFR - estimated glomerular filtration rate, NS - not statistically significant. ${ }^{\star}$ Kruskal-Wallis test

Table IV. Median levels and interquartile ranges of low molecular weight proteins in the urine of HIV patients in the subgroups: $L T C D 4+$ count $<500$ cells $/ \mu$ l and the eGFR $<90 \mathrm{ml} / \mathrm{min}$ vs. LT CD4+ count $\geq 500$ cells $/ \mu \mathrm{l}$ and the eGFR $\geq 90 \mathrm{ml} / \mathrm{min}$ with statistical analysis

\begin{tabular}{|c|c|c|c|c|c|c|c|c|}
\hline Subgroup & $\begin{array}{l}\text { EGFR } \\
\text { CD4+ }\end{array}$ & $\begin{array}{l}<90 \mathrm{ml} / \mathrm{min} \\
<500 \mathrm{cells} / \mu \mathrm{l} \\
\quad(\mathrm{A}) \\
n=14\end{array}$ & $\begin{array}{l}\text { EGFR } \\
\text { CD4+ }\end{array}$ & $\begin{array}{l}90 \mathrm{ml} / \mathrm{min} \\
500 \mathrm{cells} / \mu \mathrm{l} \\
(\mathrm{B}) \\
=23\end{array}$ & & $\begin{array}{l}\text { trol group } \\
\text { (C) }\end{array}$ & $P$-value* & $\begin{array}{l}\text { Post hoc } \\
\text { analysis }\end{array}$ \\
\hline LMWP & Me & IQR & $\mathrm{Me}$ & IQR & Me & IQR & & \\
\hline $\begin{array}{l}\mathrm{KIM}-1 \\
{[\mathrm{ng} / \mathrm{mg} \mathrm{cr} .]}\end{array}$ & 0.25 & $0.07-0.31$ & 0.07 & $0.03-0.15$ & 0.03 & $0.02-0.08$ & $<0.001$ & $\begin{array}{c}A: C<0.001 \\
B: C=N S \\
A: B=N S\end{array}$ \\
\hline $\begin{array}{l}\text { NGAL } \\
\text { [ng/mg cr.] }\end{array}$ & 33.59 & $18.19-47.46$ & 18.06 & $7.27-36.28$ & 7.57 & $3.65-14.57$ & $<0.001$ & $\begin{array}{c}A: C<0.001 \\
B: C=0.01 \\
A: B=N S\end{array}$ \\
\hline $\begin{array}{l}\text { GST- } \alpha \\
\text { [ng/mg cr.] }\end{array}$ & 2.42 & $1.86-5.73$ & 2.13 & $1.69-5.57$ & 1.72 & $1.06-2.80$ & 0.012 & $\begin{array}{c}A: C=0.03 \\
B: C=N S \\
A: B=N S\end{array}$ \\
\hline $\begin{array}{l}\text { GST- } \pi \\
{[\mathrm{ng} / \mathrm{mg} \mathrm{cr} .]}\end{array}$ & 3.36 & $2.47-5.81$ & 2.93 & $1.98-6.96$ & 3.24 & $2.18-4.14$ & NS & $\begin{array}{l}A: C=N S \\
B: C=N S \\
A: B=N S\end{array}$ \\
\hline $\begin{array}{l}\text { NPT } \\
\text { [ng/mg cr.] }\end{array}$ & 415.39 & $177.26-571.27$ & 43.37 & $29.92-80.62$ & 59.76 & $30.95-115.15$ & $<0.001$ & $\begin{array}{c}A: C=0.002 \\
B: C=N S \\
A: B<0.001\end{array}$ \\
\hline
\end{tabular}

ME - median, IQR - interquartile ranges, LMWP - low molecular weight proteins, eGFR - estimated glomerular filtration rate, NS - not statistically significant. * Kruskal-Wallis test

Our results revealed a statistically significant increase of KIM-1, NGAL and GST- $\alpha$ levels in patient subgroups regardless of lymphocyte count compared to the control group. The levels of these parameters were higher in HIV-infected patients with an LT CD4+ count $<500$ cells $/ \mu$ l than in HIV-infected patients with LT CD4+ $\geq 500$ cells $/ \mu$ l but not statistically significant. This suggests that these parameters (KIM-1, NGAL and GST- $\alpha$ ) more strongly reflect the intensity of HIV infection related to the reduced count of LT CD4+ and kidney dysfunction than the other examined LMWP.

The cells of the immune system, primarily LT CD4+, are the sites of HIV replication, leading to progressive degradation of the host's immune system. The LT CD4+ count reflects the condition of the immune system in these patients and is constantly monitored during CART. The increase 
Table V. Median levels and interquartile ranges of low molecular weight proteins in the urine of HIV patients in the subgroups I-IV, separated on the basis of treatment with statistical analysis

\begin{tabular}{|c|c|c|c|c|}
\hline Patient subgroup & Median & IQR & $P$-value* & Post hoc analysis \\
\hline \multicolumn{5}{|l|}{ KIM-1 [ng/mg cr.] } \\
\hline 1 & 0.16 & $0.07-0.29$ & \multirow[t]{5}{*}{0.003} & \multirow{5}{*}{$\begin{array}{c}I: C=0.002 ; I: I I=N S ; I I: I V=N S \\
I I: C=N S ; I: I I I=N S ; I I: I V=N S \\
I I I: C=N S ; I: I V=N S ; I I: I I I=N S \\
I V: C=N S\end{array}$} \\
\hline II & 0.09 & $0.04-0.14$ & & \\
\hline III & 0.11 & $0.07-0.17$ & & \\
\hline IV & 0.07 & $0.04-0.16$ & & \\
\hline Control group (C) & 0.03 & $0.02-0.08$ & & \\
\hline \multicolumn{5}{|l|}{ NGAL [ng/mg cr.] } \\
\hline I & 25.17 & $17.88-42.82$ & \multirow[t]{5}{*}{$<0.001$} & \multirow{5}{*}{$\begin{array}{c}\mathrm{I}: C<0.001 ; \mathrm{I}: \mathrm{II}=\mathrm{NS} ; \mathrm{II}: \mathrm{IV}=\mathrm{NS} \\
\mathrm{II}: \mathrm{C}<0.001 ; \mathrm{I}: I I=\mathrm{NS} ; \mathrm{III}: \mathrm{IV}=\mathrm{NS} \\
\mathrm{III}: C<0.001 ; \mathrm{I}: \mathrm{IV}=\mathrm{NS} ; \mathrm{II}: I I=\mathrm{NS} \\
\mathrm{IV}: \mathrm{C}<0.001\end{array}$} \\
\hline ॥ & 18.36 & $10.96-43.26$ & & \\
\hline III & 28.09 & $13.23-40.62$ & & \\
\hline IV & 11.21 & $5.09-20.54$ & & \\
\hline Control group (C) & 7.57 & $3.65-14.57$ & & \\
\hline \multicolumn{5}{|l|}{ GST- $\alpha$ [ng/mg cr.] } \\
\hline 1 & 2.72 & $1.84-5.39$ & \multirow[t]{5}{*}{ NS } & \multirow{5}{*}{$\begin{array}{c}I: C=N S ; I: I I=N S ; I I: I V=N S \\
I I: C=N S ; I: I I I=N S ; I I: I V=N S \\
I I I: C=N S ; I: I V=N S ; I I: I I I=N S \\
I V: C=N S\end{array}$} \\
\hline II & 2.81 & $1.77-3.66$ & & \\
\hline III & 2.21 & $1.94-6.49$ & & \\
\hline IV & 2.62 & $1.55-5.85$ & & \\
\hline Control group (C) & 1.72 & $1.06-2.80$ & & \\
\hline \multicolumn{5}{|l|}{$\mathrm{GST}-\pi$ [ng/mg cr.] } \\
\hline 1 & 2.67 & $1.78-5.06$ & \multirow[t]{5}{*}{$<0.001$} & \multirow{5}{*}{$\begin{array}{c}\mathrm{I}: C=N S ; I: I I=N S ; I I: I V=0.03 \\
I I: C=N S ; I: I I I=N S ; I I: I V=N S \\
I I I: C=0.03 ; I: I V=N S ; I I: I I I=N S \\
I V: C=0.02\end{array}$} \\
\hline II & 2.71 & $1.78-4.82$ & & \\
\hline III & 6.65 & $3.10-11.92$ & & \\
\hline IV & 6.33 & $2.98-13.53$ & & \\
\hline Control group (C) & 3.24 & $2.18-4.14$ & & \\
\hline \multicolumn{5}{|l|}{ NPT [ng/mg cr.] } \\
\hline I & 448.41 & $334.25-756.28$ & \multirow[t]{5}{*}{$<0.001$} & \multirow{5}{*}{ 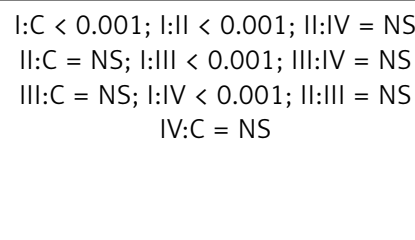 } \\
\hline II & 59.43 & $40.49-125.54$ & & \\
\hline III & 28.27 & $17.77-66.57$ & & \\
\hline IV & 101.42 & $37.28-322.49$ & & \\
\hline Control group (C) & 59.76 & $30.95-115.15$ & & \\
\hline
\end{tabular}

$I Q R$ - interquartile ranges, I-IV - patient subgroups, I - patients on CART including TDF with eGFR $<90 \mathrm{ml} / \mathrm{min}$, II - patients on cART including TDF with eGFR $\geq 90 \mathrm{ml} / \mathrm{min}$, III - patients on CART without TDF with eGFR $\geq 90 \mathrm{ml} / \mathrm{min}, I V$ - cART-naïve patients with eGFR $\geq 90 \mathrm{ml} / \mathrm{min}$, NS - not statistically significant. *Kruskal-Wallis test

of LT CD4+ count testifies to the effectiveness of therapy, while a decline indicates the progression of infection, which is not only related to the patient's clinical condition but also affects the kidney function [11]. Di Biaga et al. [12] observed a relationship between low $L T C D 4+$ count and the occurrence of renal abnormalities in HIV-infected patients, which demonstrates the negative effect of the intensity of HIV infection on renal function.

From our present results, it can be seen that the parameters most reflecting renal function impairment, based on the eGFR value, were KIM-1, NGAL, and especially NPT. The levels of these parameters were higher in HIV-infected patients with $\mathrm{eGFR}<90 \mathrm{ml} / \mathrm{min}$ than in HIV-infected pa- tients with eGFR $\geq 90 \mathrm{ml} / \mathrm{min}$ but not significantly statistically for KIM-1 and NGAL. The level of NPT was statistically significantly higher, by 7 times, in HIV-infected patients with decreased eGFR, below $<90 \mathrm{ml} / \mathrm{min}$, compared to the control group, and was statistically significantly higher than in HIV-infected patients with eGFR $\geq 90 \mathrm{ml} / \mathrm{min}$. In our study, NPT showed a strong negative correlation with the eGFR value, which indicates that its increase is associated with renal dysfunction in HIV-infected patients.

In the present study we also investigated the levels of LMWP in HIV-infected patients divided into subgroups depending upon the CART and in relation to the eGFR value. The analysis was car- 
ROC of NPT in I subgroup

Youden's Index $=0.96$; Cut off 202.83

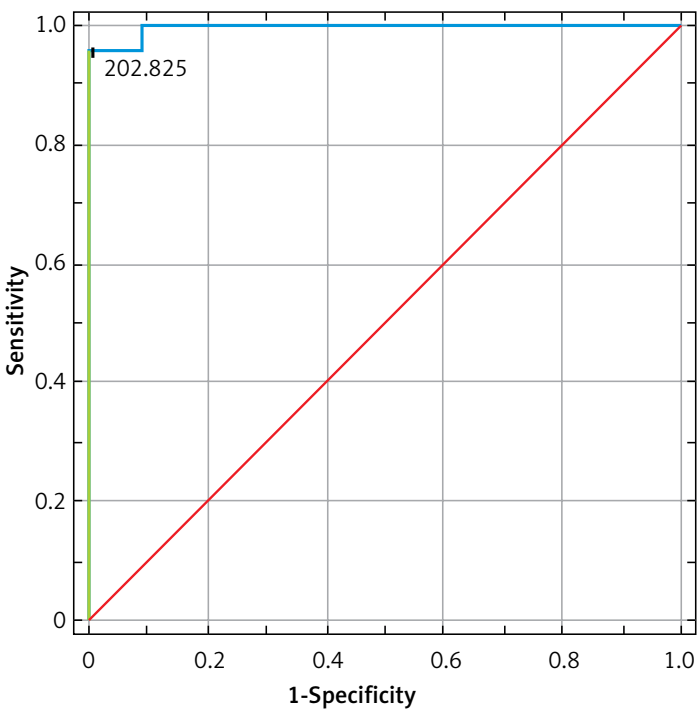

ROC of NPT in I subgroup

Youden's Index $=0.53$; Cut off 0.10

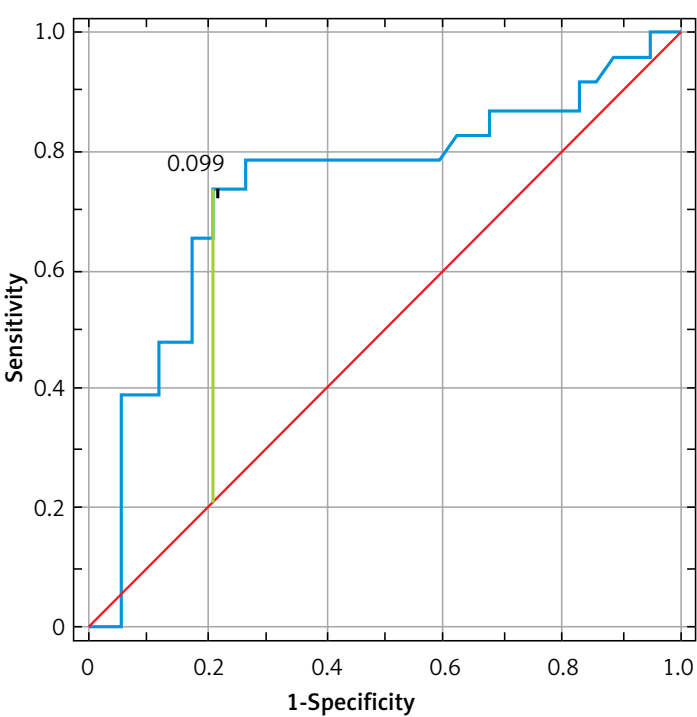

ROC of NGAL in III subgroup

Youden's Index $=0.71$; Cut off 21.36

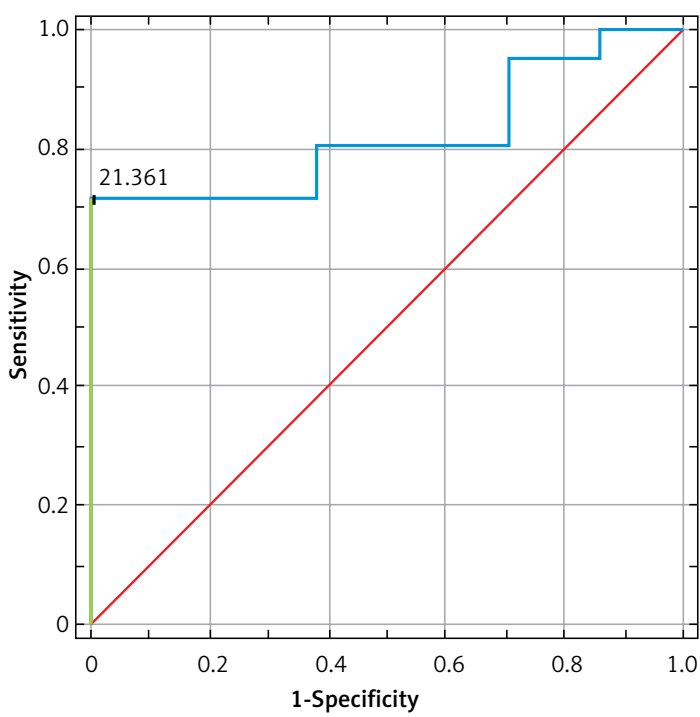

ROC of NGAL in I subgroup

Youden's Index $=0.69$; Cut off 17.88

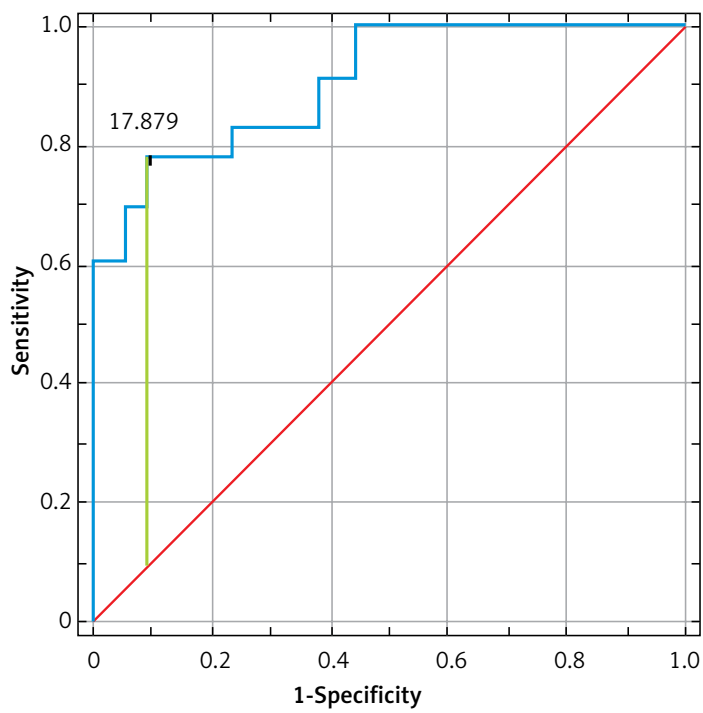

ROC of NPT in I subgroup

Youden's Index $=0.38$; Cut off 1.82

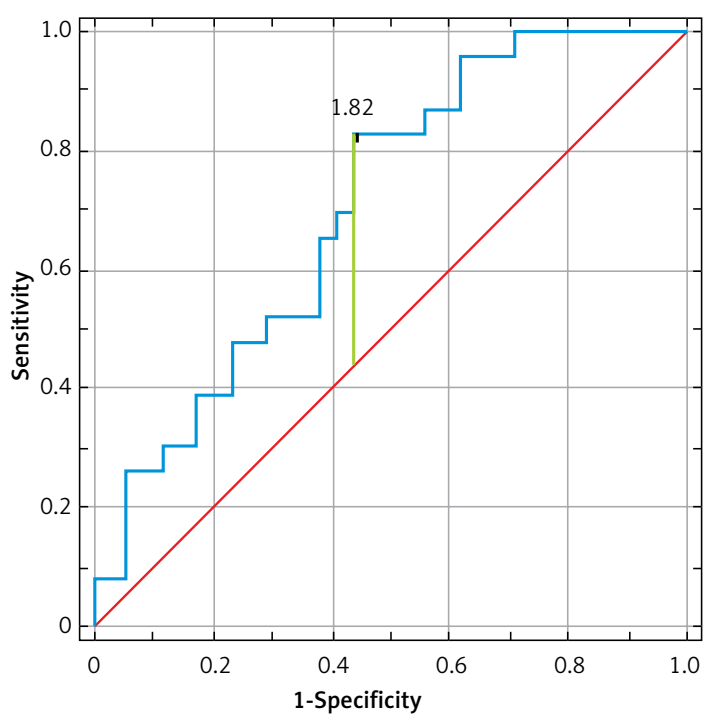

ROC of GST- $\pi$ in III subgroup

Youden's Index $=0.41$; Cut off 4.19

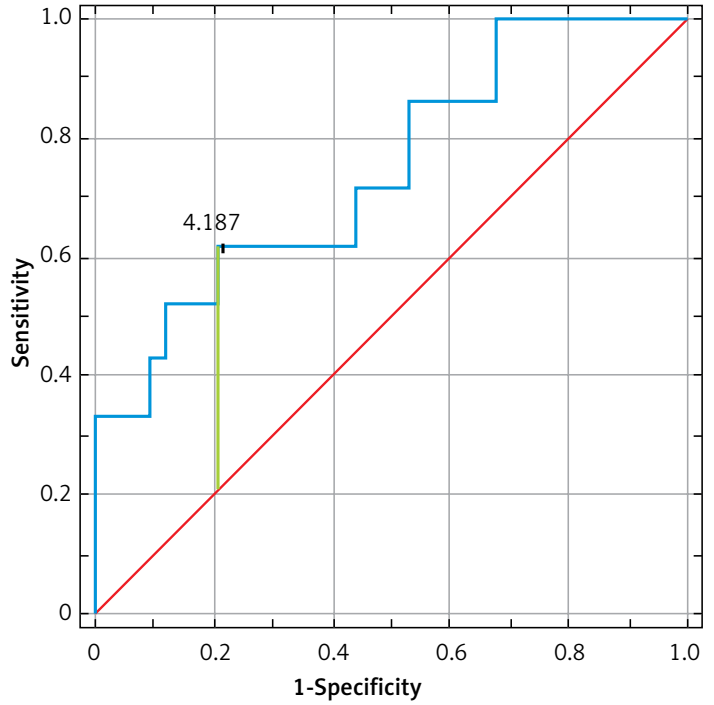

Figure 3. ROC curves of selected parameters in the subgroups separated on the basis of treatment (I and III) 
Table VI. Diagnostic value of parameters in selected subgroups

\begin{tabular}{|c|c|c|c|c|c|c|}
\hline Diagnostic value & $\begin{array}{l}\text { Se (\%) } \\
\text { [Cl 95\%] }\end{array}$ & $\begin{array}{c}\text { Sp (\%) } \\
\text { [Cl 95\%] }\end{array}$ & $\begin{array}{l}\text { PPV (\%) } \\
\text { [CI 95\%] }\end{array}$ & $\begin{array}{l}\text { NPV (\%) } \\
\text { [CI 95\%] }\end{array}$ & $\begin{array}{c}\text { LR+ } \\
{[\mathrm{Cl} 95 \%]}\end{array}$ & $\begin{array}{c}\text { LR- } \\
{[\text { CI 95\%] }}\end{array}$ \\
\hline $\begin{array}{l}\mathrm{KIM}-1 \\
\mathrm{CD} 4+<500 \mathrm{cell} / \mu \mathrm{l}\end{array}$ & $\begin{array}{c}75.6 \\
(59.7-87.6)\end{array}$ & $\begin{array}{c}67.8 \\
(49.5-82.6)\end{array}$ & $\begin{array}{c}73.8 \\
(62.7-82.5)\end{array}$ & $\begin{array}{c}69.7 \\
(56.1-80.5)\end{array}$ & $\begin{array}{c}2.3 \\
(1.4-3.9)\end{array}$ & $\begin{array}{c}0.4 \\
(0.2-0.6)\end{array}$ \\
\hline $\begin{array}{l}\text { NGAL } \\
\text { CD4+ }<500 \text { cell } / \mu \mathrm{l}\end{array}$ & $\begin{array}{c}53.7 \\
(37.4-69.3)\end{array}$ & $\begin{array}{c}94.1 \\
(80.3-99.3)\end{array}$ & $\begin{array}{c}91.7 \\
(73.6-97.8)\end{array}$ & $\begin{array}{c}62.7 \\
(54.5-70.3)\end{array}$ & $\begin{array}{c}9.12 \\
(2.3-36.1)\end{array}$ & $\begin{array}{c}0.4 \\
(0.4-0.7)\end{array}$ \\
\hline $\begin{array}{l}\text { NPT } \\
\text { GFR }<90 \mathrm{ml} / \mathrm{min}\end{array}$ & $\begin{array}{c}82.1 \\
(63.1-93.9)\end{array}$ & $\begin{array}{c}91.2 \\
(86.3-98.1)\end{array}$ & $\begin{array}{c}88.5 \\
(72.0-95.8)\end{array}$ & $\begin{array}{c}86.1 \\
(73.6-93.3)\end{array}$ & $\begin{array}{c}9.3 \\
(3.1-27.8)\end{array}$ & $\begin{array}{c}0.2 \\
(0.09-0.4)\end{array}$ \\
\hline $\begin{array}{l}\mathrm{KIM}-1 \\
\mathrm{GFR}<90 \mathrm{ml} / \mathrm{min}\end{array}$ & $\begin{array}{c}67.9 \\
(47.6-84.1)\end{array}$ & $\begin{array}{c}79.4 \\
(62.1-91.3)\end{array}$ & $\begin{array}{c}73.1 \\
(52.2-84.6)\end{array}$ & $\begin{array}{c}75.9 \\
(63.0-84.10) \\
\end{array}$ & $\begin{array}{c}3.3 \\
(1.6-6.7)\end{array}$ & $\begin{array}{c}0.4 \\
(0.2-0.7)\end{array}$ \\
\hline $\begin{array}{l}\text { NGAL } \\
\text { GFR }<90 \mathrm{ml} / \mathrm{min}\end{array}$ & $\begin{array}{c}75.2 \\
(55.1-89.3)\end{array}$ & $\begin{array}{c}91.2 \\
(76.3-98.1)\end{array}$ & $\begin{array}{c}87.8 \\
(69.6-95.5) \\
\end{array}$ & $\begin{array}{c}81.6 \\
(69.8-89.5)\end{array}$ & $\begin{array}{c}8.5 \\
(2.8-25.6) \\
\end{array}$ & $\begin{array}{c}0.2 \\
(0.1-0.5)\end{array}$ \\
\hline $\begin{array}{l}\text { GST- } \alpha \\
\text { GFR }<90 \mathrm{ml} / \mathrm{min}\end{array}$ & $\begin{array}{c}82.1 \\
(63.1-93.9)\end{array}$ & $\begin{array}{c}55.9 \\
(37.9-72.8) \\
\end{array}$ & $\begin{array}{c}60.5 \\
(50.3-69.9)\end{array}$ & $\begin{array}{c}79.2 \\
(61.9-89.9)\end{array}$ & $\begin{array}{c}1.8 \\
(1.2-2.8) \\
\end{array}$ & $\begin{array}{c}0.3 \\
(0.1-0.7)\end{array}$ \\
\hline $\begin{array}{l}\text { NPT } \\
\text { I subgroup }\end{array}$ & $\begin{array}{c}95.7 \\
(78.1-99.9)\end{array}$ & $\begin{array}{c}91.2 \\
(76.3-98.1)\end{array}$ & $\begin{array}{c}88.0 \\
(71.3-95.6)\end{array}$ & $\begin{array}{c}96.9 \\
(82.0-99.5)\end{array}$ & $\begin{array}{c}10.8 \\
(3.7-32.1)\end{array}$ & $\begin{array}{c}0.04 \\
(0.0-0.3)\end{array}$ \\
\hline $\begin{array}{l}\text { NGAL } \\
\text { I subgroup }\end{array}$ & $\begin{array}{c}78.3 \\
(56.3-92.5)\end{array}$ & $\begin{array}{c}91.2 \\
(76.3-98.1)\end{array}$ & $\begin{array}{c}85.7 \\
(66.6-94.8) \\
\end{array}$ & $\begin{array}{c}86.1 \\
(73.9-93.1)\end{array}$ & $\begin{array}{c}8.9 \\
(2.9-26.7) \\
\end{array}$ & $\begin{array}{c}0.2 \\
(0.1-0.5) \\
\end{array}$ \\
\hline $\begin{array}{l}\text { KIM-1 } \\
\text { I subgroup }\end{array}$ & $\begin{array}{c}73.9 \\
(51.6-89.8)\end{array}$ & $\begin{array}{c}79.4 \\
(62.1-91.3)\end{array}$ & $\begin{array}{c}70.8 \\
(54.6-83.1)\end{array}$ & $\begin{array}{c}81.8 \\
68.9-90.1)\end{array}$ & $\begin{array}{c}3.5 \\
(1.8-7.3)\end{array}$ & $\begin{array}{c}0.3 \\
(0.2-0.7)\end{array}$ \\
\hline $\begin{array}{l}\text { GST- } \alpha \\
\text { I subgroup }\end{array}$ & $\begin{array}{c}82.6 \\
(61.2-95.0)\end{array}$ & $\begin{array}{c}55.8 \\
(37.9-72.8)\end{array}$ & $\begin{array}{c}55.9 \\
(45.4-65.9)\end{array}$ & $\begin{array}{c}82.6 \\
(65.0-92.4)\end{array}$ & $\begin{array}{c}1.8 \\
(1.2-2.9)\end{array}$ & $\begin{array}{c}0.3 \\
(0.1-0.8)\end{array}$ \\
\hline $\begin{array}{l}\text { NGAL } \\
\text { III subgroup }\end{array}$ & $\begin{array}{c}71.4 \\
(47.8-88.7)\end{array}$ & $\begin{array}{c}97.1 \\
(84.7-99.9)\end{array}$ & $\begin{array}{c}93.7 \\
(68.1-99.1)\end{array}$ & $\begin{array}{c}84.6 \\
73.6-91.6)\end{array}$ & $\begin{array}{c}24.29 \\
(3.5-171)\end{array}$ & $\begin{array}{c}0.2 \\
(0.1-0.6)\end{array}$ \\
\hline $\begin{array}{l}\text { GST- } \pi \\
\text { III subgroup }\end{array}$ & $\begin{array}{c}61.9 \\
(38.4-81.9)\end{array}$ & $\begin{array}{c}79.4 \\
(62.1-91.3)\end{array}$ & $\begin{array}{c}65.0 \\
(47.0-79.6)\end{array}$ & $\begin{array}{c}77.1 \\
(65.6-85.7)\end{array}$ & $\begin{array}{c}3.0 \\
(1.4-6.3)\end{array}$ & $\begin{array}{c}0.4 \\
(0.3-0.8)\end{array}$ \\
\hline
\end{tabular}

$\mathrm{Cl}$ - confidence interval, Se - sensitivity, Sp - specificity, PPV - positive predictive value, NPV - negative predictive value, $L R$ - likelihood ratio

ried out in four subgroups (I-IV), as described in detail in the Material and methods section. Nephrotoxicity is reported with almost all drugs used in CART; however, renal diseases are more often associated with TDF application than with other antiretroviral drugs used to date [13]. Tenofovir is excreted unchanged by the kidneys by glomerular filtration and active tubular secretion. In most reported cases of TDF-associated nephropathy, Fanconi syndrome was found, i.e. a generalized proximal nephropathy [14]. Previous evidence from case report and cohort studies points to the association of prolonged TDF use with renal damage [15]. Despite this fact, according to recommendations of the EACS tenofovir is used in imitation therapy either as tenofovir disoproxil fumarate (TDF) or the subsequent pro-drug formulation tenofovir alafenamide (TAF). Both versions can be nephrotoxic, TDF more so, but other side effects can exclude the use of TAF in a certain patient $[16,17]$.

There are currently various strategies to reduce long-term exposure to antiretrovirals. To reduce exposure to antiretroviral drugs, dual therapy can be introduced. The two-drug regimen (2DR) is a simplified treatment scheme for HIV infection, which is limited to administering to the patient only two antiretrovirals. The European Commission issued a marketing authorization in 2018 for the world's first dual drug therapy used to treat HIV infection (the drug Juluca) $[18,19]$.

Juluca can be used as a complete treatment regimen for HIV infection to replace the current antiretroviral regimen in adults who have been virologically inhibited for at least 6 months. Clinical studies of this preparation show that the drug is well tolerated, is metabolizable and offers additional benefits, such as improving the lipid profile, improving bone mineral density and reducing bone resorption. Undoubtedly, longer observation of the effects of this drug therapy is needed, but this dual scheme seems to be a promising strategy for patients infected with HIV [20].

In terms of applied CART, the best parameters in the assessment of kidney injury in HIV-infected patients were NGAL, GST- $\pi$ and NPT. The high levels of NGAL observed in HIV-infected patients reflect kidney damage independently of the CART therapy.

Our study also showed that the highest level of NPT was in subgroup I with patients on CART including TDF with a reduced eGFR value.

Different results were observed in the case of GST- $\pi$, whose median levels were highest in subgroup III and IV. The high level in cART-naïve patients suggests that this parameter may reflect the state of renal function resulting from direct ac- 
tion of the virus. Further channels that are the location of GST- $\pi$ are made of a thick epithelial layer with high electrical resistance, which makes them less susceptible to toxic damage than proximal tubules [21]. The differences in the concentration of GST- $\pi$ isoenzyme among treated and untreated patients found in our study suggest that the determination of this isoenzyme could be a clue in deciding whether to start CART. This is especially important in cases where the viral load is not yet an indication of the need to implement therapy, especially in the case of HIVAN patients with undetectable levels of HIV-RNA in the blood [22].

Kidney injury molecule- 1 is undetectable in the tissues of a healthy kidney. However, it exhibits intensified expression and increased synthesis in response to renal tubule damage. It has been shown that there is a specific increase of KIM-1 in the case of ischemic and toxic kidney damage. The increase in the concentration of this glycoprotein may imply parenchymal dysfunction. On the other hand, KIM-1 may, as a result of interaction with other molecules, form a protective film on the surface of the proximal tubule cells and thereby modulate the course of kidney damage [13-25].

Jotwani et al. [26] showed that the urine level of KIM-1 was $12 \%$ higher in HIV-infected patients as compared with HIV-uninfected participants. HIV infection was associated with a $16 \%$ higher urine $\mathrm{KIM}-1 /$ creatinine ratio, demonstrating the usefulness of urinary KIM-1 as a marker for screening and quantifying kidney injury in HIV-infected individuals.

A higher concentration of KIM-1/creatinine was also observed in HIV-infected patients receiving antiretroviral therapy as compared to healthy individuals, although the difference was not statistically significant [27].

Neutrophil gelatinase associated lipocalin present in the plasma undergoes glomerular filtration, and then is mostly reabsorbed in the proximal tubules by endocytosis. So the presence of NGAL in the urine is caused by the impairment of reabsorption resulting from damage to the proximal tubules. Additionally, the reason for its possible detection in urine may also be increased de novo synthesis of NGAL in the subsequent sections of the nephron, especially in Henle's loop and distal tubules [28].

The use of NGAL measurements in monitoring of CKD is proposed, where NGAL levels in urine of these patients increase significantly. In studies conducted by Sola-Del Valle et al. $[29,30]$ significantly elevated values of urinary NGAL concentration were observed in HIV-associated nephropathy (HIVAN) patients in comparison with other types of chronic kidney disease. The present authors support the usefulness of this parameter in identifying HIV-related nephropathy.
In the study by Silva et al. [31] HIV patients were assigned to 3 groups: without CART, CART with TDF, and CART with zidovudine. In the biological samples (serum and urine) syndecan-1, NGAL, monocyte chemoattractant protein-1 (MCP-1) and KIM1 were measured. The authors found higher levels of KIM-1 in the TDF group, similar to the results obtained by us. NGAL was higher in HIV patients.

Hall et al. [13] observed that HIV-infected patients had higher median urine levels of NGAL than uninfected patients, and HIV infection was associated with a mean 19\% (4-36\%) higher NGAL/ creatinine ratio, which suggests that HIV-infected patients had more extensive kidney injury than uninfected patients [13]. In HIV-positive outpatients, an elevated urinary NGAL/creatinine ratio was found in $67 \%$ of patients [32]. Additionally, urinary NGAL is elevated even before the eGFR is reduced, is reflective of injury in parts of the nephron other than the glomerulus, and has independent associations with faster kidney function decline and mortality risk in HIV-infected patients [33].

In the study of Amirayan-Chevillard et al. [34] the effects of dual reverse transcriptase inhibitor (RT) therapy and highly active antiretroviral therapy (HAART) on NPT levels in patients with HIV infection were compared to HIV uninfected controls. Significantly higher plasma circulating levels of NPT were found in HIV-positive patients compared to HIV-negative controls. In patients with a high viral load ( $>100,000$ copies $/ \mathrm{ml}$ ) the NPT levels were significantly higher than in patients with a low viral load ( $<20,000$ copies/ml).

Neopterin is a nonspecific marker of a cell-mediated immune response and macrophage activation. Neopterin secretion is closely related to the ability of monocytes/macrophages to release reactive oxygen species (ROS). Therefore, not only the extent of the cellular response, but also the severity of the oxidative stress can be estimated based on NPT measurements [35, 36]. Measurements of NPT concentration in body fluids (serum, urine) are considered a sensitive parameter in monitoring the cellular immune response. Thus, the determination of its concentration is not only conducive to rapid diagnosis, but it is also useful in predicting disease progression [37].

A study by Nübling et al. [38] was conducted to assess the diagnostic sensitivity of NPT screening of blood donors with regard to the detection of HIV, hepatitis C virus (HCV), and hepatitis B virus (HBV) infection. A significant association between elevated NPT level and the very early phase of HIV-1 infection was found. No significant correlation could be observed between NPT levels and the early phase of HCV or HBV infection. The authors concluded that NPT screening of blood donors may identify cases of HIV, but not of HCV or HBV infection. 
In the study of Pecoits-Filho et al. [39] the relationship between inflammation and glomerular filtration rate (GFR) in patients was analyzed by measurement of the levels of high-sensitivity C-reactive protein (hsCRP), tumor necrosis factor-alpha (TNF-alpha), interleukin-6 (IL-6), hyaluronan, and NPT in serum and urine. Patients were subdivided into two groups according to median GFR (6.5 ml/min). Marker levels including NPT (serum/urine) were significantly greater in the subgroup with lower GFR values, and a significant negative correlation was noted between GFR and NPT. These results show that a low GFR value is associated with an inflammatory state, suggesting impaired renal elimination of proinflammatory markers including NPT.

In HIV infection, the concentration of NPT increases as the disease progresses, reaching the maximum in full-blown AIDS. A negative correlation was observed between its concentration and the LT CD4+ count in this disease. Already in the early stages of infection NPT reaches high values [18]. Uysal et al. [40] found a negative correlation between NPT, measured both in urine and in serum, and the LT CD4+ count in HIV-infected patients.

Glutathione transferases play an important role in the metabolism and detoxification of various endogenous substances and xenobiotics [41, 42]. They catalyze the coupling reactions of glutathione with, among others, drugs and environmental carcinogens. The diverse location of $\alpha$ - and $\pi$-GST in kidney cells makes it possible to use the determination of these isoenzymes in the assessment of renal function. It has been proven that GST- $\pi$ is present in the distal tubules and Henle's loop. The presence of GST- $\alpha$ is limited to the proximal tubules [43]. Changes in the levels of both isoenzymes GST- $\alpha$ and GST- $\pi$ located in different fragments of nephrons allow the site of damage to be assessed indirectly.

Only one study concerning GST- $\pi$ examination in HIV patients has been found in the available scientific literature. In the light of the fact that HIV-associated nephropathy (HIVAN) in sub-Saharan Africa remains a significant cause of morbidity and mortality in children, Nandlal et al. [44] determined the urinary concentrations of KIM-1-and GST- $\pi$ in children with idiopathic focal segmental glomerulosclerosis (FSGS) and HIVAN. A significant increase in urinary KIM-1 levels was observed in the HIVAN group compared with the HIV-positive patients, but no statistically significant differences were noted in urinary GST- $\pi$ levels in study groups. This indicates lower usefulness of GST- $\pi$ measurement to assess kidney injury in such patients.

Table VI shows the indicators (sensitivity; specificity; PPV, NPV LR+/- with $95 \% \mathrm{Cl}$ ) of the parameters tested with the best diagnostic value.
Based on the assessment of indicators determining the diagnostic value of the parameters tested, NPT, NGAL and GST $\alpha$ should be distinguished as potential parameters in screening tests of HIV-infected patients with GFR $<90 \mathrm{ml} / \mathrm{min}$ and of HIV-patients with reduced GFR (GFR $<90 \mathrm{ml}$ min) co-treated with TDF.

The value of the area under the ROC curve (AUC) in the range $0.7-0.8$ is a fair diagnostic value.

Studies conducted on patients with HIV have some limitations. First of all, HIV-infected patients are reluctant to participate in scientific research. Many patients should be eliminated from the study due to accompanying diseases or abuse of various medications or systematic use of CART. Finding clinical parameters that are non-invasive to assess early kidney dysfunction in these patients is important. Therefore, we believe that our research may be useful in monitoring the safe use of CART therapy in patients with HIV. The advantages of the research are the relatively low cost and short waiting time for the result. However, the research should be extended to more HIV-infected patients and for longer follow-up to confirm its diagnostic and clinical usefulness.

In conclusion, our study shows that the analyzed parameters are useful in the assessment of kidney dysfunction in HIV-infected patients. The NPT reflects the disease progression associated with HIV infection and may be useful for assessing the effectiveness of cART therapy. NPT, NGAL and GST $\alpha$ should be distinguished as potential parameters in screening tests of HIV-infected patients. Future studies should be conducted on larger groups of HIV patients for better estimation of diagnostic usefulness of the examined LMWP.

\section{Conflict of interest}

The authors declare no conflict of interest.

\section{References}

1. Global AIDS monitoring 2018: indicators for monitoring the 2016 United Nations Political Declaration on HIV and AIDS. UNAIDS, Geneva 2018. Available at: https://www. unaids.org/en/resources/documents/2018/GlobalAIDS-Monitoring

2. Cobucci RN, Lima PH, Souza PC et al. Assessing the impact of HAART on the incidence of defining and nondefining AIDS cancers among patients with HIV/AIDS: a systematic review. J Infect Public Health 2015; 8: 1-10.

3. Ghosn J, Taiwo B, Seedat S, Autran B, Katlama C. HIV. Lancet 2018; 392: 685-97.

4. Scarpino M, Pinzone MR, Di Rosa M, et al. Kidney disease in HIV-infected patients. Eur Rev Med Pharmaco 2013; 17: 2660-7.

5. Estrella MM, Fine DM. Screening for chronic kidney disease in HIV-infected patients. Adv Chronic Kidney Dis 2010; 17: 26-35.

6. Leszczyszyn-Pynka M, Ciejak P, Maciejewska K, et al. Hepatitis $C$ coinfection adversely affects the life expec- 
tancy of people living with HIV in northwestern Poland. Arch Med Sci 2018; 14: 554-9.

7. Jabłonowska E, Pulik P, Kalinowska A, Gąsiorowski J, Parczewski M. Dual therapy based on raltegravir and boosted protease inhibitors - the experience of Polish centers. Arch Med Sci 2018; 14: 860-4.

8. Kaboré NF, Armel Poda A, Jacques Zoungrana J, et al. Chronic kidney disease and HIV in the era of antiretroviral treatment: findings from a 10-year cohort study in a west African setting. BMC Nephrol 2019; 20: 155.

9. Ando M, Tsuchiya K, Nitta K. How to manage HIV-infected patients with chronic kidney disease in the HAART era. Clin Exp Nephrol 2012; 16: 363-72.

10. Wasung MA, Lakhmir S, Chawla LS, Madero MA. Biomarkers of renal function, which and when? Clin Chim Acta 2015; 438: 350-7.

11. Wyatt CM. Kidney disease and HIV infection. Top Antivir Med 2017; 25: 13-6.

12. Di Biagio A, Rosso R, Vitale F, et al. Risk factors for chronic kidney disease among human immunodeficiency virusinfected patients: a European case control study. Clin Nephrol 2011; 75: 518-23.

13. Hall AM. Update on tenofovir toxicity in the kidney. Pediatr Nephrol 2013; 28: 1011-23.

14. Fernandez-Fernandez B, Montoya-Ferrer A, Sanz AB, Sanchez-Nino MD, Izquierdo MC. Tenofovir nephrotoxicity: 2011 update. AIDS Res Treat 2011; 2011: 354908.

15. Ryom L, Mocroft A, Lundgren J. HIV therapies and the kidney: some good, some not so good? Curr HIV/AIDS Rep 2012; 9: 111-20.

16. EACS guidelines, Version 9.1, October 2018, 11. Available at: https://www.eacsociety.org/files/2018_guidelines-9.1-english.pdf.

17. DeJesus E, Haas B, Segal-Maurer S, et al. Superior efficacy and improved renal and bone safety after switching from a tenofovir disoproxil fumarate- to a tenofovir alafenamide-based regimen through 96 weeks of treatment. AIDS Res Hum Retroviruses 2018; 34: 337-342.

18. Cholewa K, Poleszak J, Wysokińska O, et al. JULUCA a new therapeutic opportunity for patients infected with HIV-1. World Scientific News 2019; 123: 181-91.

19. Blair HA. Dolutegravir/rilpivirine: a review in HIV-1 infection. Drugs 2018; 78: 1741-50.

20. Revuelta-Herrero JL, Chamorro-de-Vega E, RodríguezGonzález CG. Effectiveness, safety, and costs of a treatment switch to dolutegravir plus rilpivirine dual therapy in treatment-experienced HIV patients. Ann Pharmacother 2018; 52: 11-8.

21. Marchewka Z. Low molecular weight biomarkers in the nephrotoxicity. Adv Clin Exp Med 2006; 15: 1129-38.

22. Medapalli RK, Klotman PE. HIV-associated nephropathy: pathogenesis. Curr Opin Nephrol Hypertens 2011; 20: 306-11.

23. Bonventre JV. Kidney injury molecule-1 (KIM-1): a urinary biomarker and much more. Nephrol Dial Trans 2009; 24: 3265-8.

24. Timmeren MM, Bakker SJL, Vaidya VS, et al. Tubular kidney injury molecule-1 in protein-overload nephropathy. Am J Physiol Renal Physiol 2006; 291: F456-64.

25. Chaturvedi S, Farmer T, Kapke GF. Assay validation for KIM-1: human urinary renal dysfunction biomarker. Int J Biol Sci 2009; 5: 128-34.

26. Jotwani V, Scherzer R, Abraham A, et al. Does HIV infection promote early kidney injury in women? Antivir Ther 2014; 19: 79-87.

27. Jablonowska E, Wójcik K, Piekarska A. Urine liver-type fatty acid-binding protein and kidney injury molecule-1 in HIV-infected patients receiving combined antiretroviral treatment based on tenofovir. AIDS Res Hum Retroviruses 2014; 30: 363-9.

28. Tsigou E, Psallida V, Demponeras C, Boutzouka E, Baltopoulos $\mathrm{G}$. Role of new biomarkers: functional and struc tural damage. Crit Care Res Pract 2013; 2013: 361078.

29. Sola-Del Valle DA, Mohan S, Cheng JT, Paragas NA Sise ME. Urinary NGAL is a useful clinical biomarker of HIV-associated nephropathy. Nephrol Dial Transplant 2011; 26: 2387-90.

30. Dobreka $Ł$, Thor P. Novel biomarkers of acute kidney in jury and chronic kidney disease. Polish Annals of Medicine 2017; 24: 84-9.

31. Silva Junior GS, Sobral D, Cavalcante MG, Meneses G, Martins A, Daher E. Novel biomarkers of kidney injury and endothelial dysfunction among HIV patients. Int J Infect Dis 2018; 73 Supplement: 252.

32. Campbell LJ, Dew T, Salota R, et al. Total protein, albumin and low-molecular-weight protein excretion in HIV-positive patients. BMC Nephrol 2012; 13: 85.

33. Peralta CA, Scherzer R, Grunfeld C, et al. Urinary biomarkers of kidney injury are associated with all-cause mortality in the Women's Interagency HIV Study (WIHS). HIV Med 2014; 15: 291-300.

34. Amirayan-Chevillard N, Tissot-Dupont H, Obadia Y, Gallais H, Mege JL, Capo C. Highly active antiretroviral therapy (HAART) and circulating markers of immune activation: specific effect of HAART on neopterin. Clin Diagn Lab Immunol 2000; 7: 832-4.

35. Eisenhut M. Neopterin in diagnosis and monitoring of infectious diseases. J Biomark 2013; 2013: 196432.

36. Zielińska I, Czerwionka-Szaflarska M. Wartość neopteryny jako wskaźnika diagnostycznego, monitorującego i rokowniczego w praktyce klinicznej. Przegląd Pediatryczny 2008; 38: 130-3.

37. Michalak $Ł$, Bulska M, Strząbała K, Szcześniak P. Neo pterin as a marker of cellular immunological response. Postepy Hig Med Dosw 2017; 71: 727-36.

38. Nübling CM, Chudy M, Volkers P, Löwer J. Neopterin levels during the early phase of human immunodeficiency virus, hepatitis $C$ virus, or hepatitis $B$ virus infection. Transfusion 2006; 46: 1886-91.

39. Pecoits-Filho R, Heimburger O, Barany P, et al. Associations between circulating inflammatory markers and residual renal function in CRF patients. Am J Kidney Dis 2003; 41: 1212-8.

40. Uysal HK, Sohrabi P, Habip Z, et al. Neopterin and soluble CD14 levels as indicators of immune activation in cases with indeterminate pattern and true positive HIV-1 infection. PLoS One 2016; 11: e0152258.

41. Chikezie PC. Glutathione S-transferase activity in diagnostic pathology. Metabolomics 2015; 5: 4.

42. Wu B, Dong D. Human cytosolic glutathione transferases: structure, function, and drug discovery. Trends Pharmacol Sci 2012; 33: 656-68.

43. Sarvary E, Nemes B, Jaray J, et al. Prediction of early graft function by the measurement of donor urinary glutathione S-tansferases. Transplantation 2000; 69: 1397402.

44. Nandlal L, Bhimma R, Naicker T. The role of kidney injury molecule-1, interleukin-18 and glutathione-S-transferase- $\pi$ in pediatric HIV-associated nephropathy. SAJCH 2018; 12: 68-72. 